\title{
Relationship between anti-oxidant capacity and manganese accumulation in the soft tissues of two freshwater molluscs: Unio pictorum mancus (Lamellibranchia, Unionidae) and Viviparus ater (Gastropoda, Prosobranchia)
}

\author{
Luigi CAMPANELLA*, Tania GATTA and Oscar RAVERA ${ }^{1)}$ \\ Department of Chemistry, University "La Sapienza", P.le Aldo Moro 5, 00185 Rome, Italy \\ ${ }^{1)}$ CNR Institute of Ecosystem Study, L.go Tonolli 50, 28922 Verbania Pallanza (VB), Italy \\ *e-mail corresponding author: luigi.campanella@uniroma1.it
}

\begin{abstract}
Manganese is an element of great importance in the life cycle of plants and animals. For example, it plays an essential role as an activator of various enzymatic systems such as isoenzymes of superoxide dismutase. Freshwater Unionidae concentrate relatively large amounts of manganese in their tissues, but little is known about the physiological role of this metal. The aim of this research is to acquire a better knowledge of the role of manganese in molluscs which accumulate large amounts of this metal and in those with low manganese concentrations. As manganese is one of the metals present in the superoxide molecule, the possible relationship between manganese concentration in the soft tissues of molluscs and the antioxidant capacity of the metal can usefully be tested. To this end two species of molluscs were analysed: Unio pictorum mancus (Lamellibranchia, Unionidae), which is very rich in manganese, and Viviparus ater (Gastropoda, Prosobranchia) which has a low manganese content. The adults of both species were analysed for manganese concentration by ICP, and for antioxidant capacity as RAC (Relative Antioxidant Capacity) by a superoxide dismutase method. The results clearly demonstrate the active role played by manganese against free radicals and consequently the important role of the metal in protecting Unio against oxidative stress. The low concentration of manganese in Viviparus may be the result of the effective excretion of this metal, as was found for ruthenium.
\end{abstract}

Key words: metal bioaccumulators, superoxide dismutase (SOD), relative antioxidant capacity (RAC), isoenzymes, freshwater molluscs

\section{INTRODUCTION}

Manganese is an essential trace metal for plant and animal metabolism. For example, manganese plays an important role in the accumulation of nitrate and carbon dioxide assimilation in plants, and activates a number of enzymatic systems in different animal species (Malmstron \& Rosenberg 1959). High concentrations of manganese have been measured in the soft tissues of freshwater mussels since the beginning of the $20^{\text {th }}$ century (Bradley 1970a; 1970b).

The first data on many trace element concentrations in marine animals (including $\mathrm{Mn}$ concentration in Lamellibranchs) were reported by Vinogradov (1953), and amplified by Fukai \& Meinke (1959).

Radiomanganese (Mn-54) is presumed to originate from the activation of Fe-54 and Mn-55 in nuclear weapons in the Pacific area after the $2^{\text {nd }}$ World War. Lowman (1960) was the first to identify this artificial radioisotope in water, plankton, molluscs and fish near the Marshall Islands. Very high concentrations of Mn54 were measured in the soft tissues of the Lamellibranch Tridacna.

In this context, an interesting question seemed to be whether the Mn-54 present in the fall-out from the Pacific weapons had also contaminated European aquatic environments. In September 1960, Mn-54 was measured in Unionidae (Unio and Anodonta) collected in Lago Maggiore and in nearby Lake Varese (Northern Italy); these mussels were found to have a great capacity for accumulating this radionuclide. At that time, Mn-54 could not be detected in fall-out, lake water, sediment, macrophytes, gastropods or fish samples collected in the same area, due to the extremely low activity of the radioisotope (Ravera \& Vido 1961).

In Unionidae, the highest Mn-54 concentrations were found in the mantle and the gills, the lowest in the extrapalleal liquid. The distribution of Mn-54 in the mussel body was compared with that of stable manganese. Since the two distributions were strikingly similar, it is probable that the Mn-54 introduced into the lake was in a form similar to that for stable manganese, at least from the point of view of the availability to the mussels (Gaglione \& Ravera 1964). Other molluscs (e.g. Viviparus ater) living in the same habitat as Unionidae concentrate such a low amount of Mn-54 that it could not be quantified by the commonly used methods (Gaglione \& Ravera 1964).

The mean concentration of stable manganese in the soft tissues of Unio pictorum collected from 12 Northern Italian lakes was $7.5 \pm 6.3 \mathrm{mg} \cdot \mathrm{g}^{-1}$ (dry weight) with a minimum of $2.23 \mathrm{mg} \cdot \mathrm{g}^{-1} \mathrm{dw}$ in Lake Mergozzo and a maximum of $15.26 \mathrm{mg} \cdot \mathrm{g}^{-1} \mathrm{dw}$ in Lake Montorfano (Ravera et al. 2003b). These values suggest that 
Unionidae are useful indicators of stable and radioactive manganese.

Since the 1960s, freshwater and marine mussels have been used as indicators for radioisotopes and toxic substances because of their capacity to accumulate these pollutants without evident consequences. The resistance of the mussel to these pollutants is due to their detoxification mechanisms, such as their capacity for concentrating pollutants in the shell, inactivating metals by binding them to thioneins, and sequestering them in calcareous granules distributed in their tissues. Bivalves were later used as indicators of persistent organic pollutants (e.g. aromatic hydrocarbons, biocides), which due to their low enzymatic activity are scarcely metabolised (Phillips 1977). Mussels are also used to assess the biological effects of pulp and paper mill effluent in marine environments (Gravato et al. 2005). Jorge \& Moreira (2005) used Perna perna larvae to test, in laboratory conditions, the toxicity of various pollutants. The foremost example of this type of biomonitoring is the "Mussel Watch Programme", which uses bivalves (Mytilus and Ostrea) to monitor Pacific and Atlantic coastal zones of the U.S.A. (O'Connors et al. 1994). The advantages and disadvantages of such monitoring are discussed in other papers (e.g. Beone \& Ravera 2003; Ravera 2004).

Little is known about the physiological role of manganese in the mussel. Pelseneer (1935) hypothesized that manganese in bivalves is the metal of a respiratory pigment called "acroglobulin", which had the same function as copper in hemocyanin and iron in haemoglobin. Vinogradov (1953) accepted this hypothesis, whereas Grassé (1960) did not agree that "acroglobulin" is a respiratory pigment.

According to Bowen (1950) the manganese concentration in Hymenoptera is too high to be explained by its role in enzymatic activity; more likely the manganese accumulation in these insects is a combined effect of their poor capacity for selecting manganese and the low excretion rate for the element.

The poor capacity of bivalves for selecting heavy metals has been clearly demonstrated for manganese, which is incorporated into their tissues through the same pathway as calcium, an element characterised by a similar ionic radius value (Markich \& Jeffree 1994).

This study is an attempt to acquire better information on the physiological role played by manganese in Unio pictorum mancus by establishing a relationship between manganese concentrations and RAC (Relative Antioxidant Capacity) in the soft tissues of Unio. The same relationship was tested for a mollusc gastropod (Viviparus ater), which, unlike Unio pictorum mancus, is characterised by a low concentration of manganese in its tissues. This comparison was made to contribute to our understanding of the fundamental role played by manganese as a metal of superoxide dismutase in an antioxidant capacity.

\section{MATERIALS}

Two species of molluscs were used for this study: the polytypic bivalve Unio pictorum mancus, L. and the gastropod Viviparus ater, Crist. and Jan. Unio pictorum mancus is widely distributed in the coastal zone of Lago Maggiore; Viviparus ater was very common in the same habitat as Unio up to 30 years ago, but is now rather rare.

The life cycle of Unio is very different from that of Viviparus. Fecundation of Unio is external, and the larvae have to pass through a parasitic phase on a fish host to metamorphose into the young mussel. Fecundation of Viviparus is internal and the embryos complete their development in the uterus of the mother.

Both molluscs take up oxygen dissolved in the water through the gills. Unio can also survive for a long periods of time at a low oxygen concentration; for example, it may spend most of the cold season buried in hypoxic and anoxic sediments, reducing its metabolic rate. To overcome these conditions, the mussel lives anaerobically utilizing glycogen and producing succinic acid as a by-product; this acid is neutralised with calcium carbonate from the inner surface of the shell. In contrast, Viviparus is not resistant to anoxic conditions.

Adults of Unio pictorum mancus and Viviparus ater were collected from the littoral zone of Lago Maggiore (Northern Italy, Varese Province). Shortly after collection the specimens were placed on ice and rushed to the laboratory where they were kept at $-20{ }^{\circ} \mathrm{C}$ until analyzed.

\section{METHODS}

\subsection{Reagents and Chemicals}

Xanthine (2,6-dihydroxy purine) sodium salt, ethylenediamine tetracetic acid (EDTA), superoxide dismutase $4980 \mathrm{U}$ mg-1, dialysis membrane (art. D-9777), supplied by Sigma (Milan, Italy). Acetone RPE, cyclohexanone RPE, hydrochloric acid (37\%) RPE, nitric acid $(65 \%)$ RPE, hydrogen peroxide $(40 \% \mathrm{~m} / \mathrm{v}) \mathrm{RE}$, supplied by Carlo Erba (Milan, Italy). Xanthine oxidase $0.39 \mathrm{U} \mathrm{mg}^{-1}$, cellulose acetate and kappa-carrageenan supplied by Fluka AG, (Buchs, Switzerland). Potassium chloride supplied by Riedel-de Haen (Seelze, Germany). Polyvinylacetate, supplied by Aldrich (Germany). KCl 3 mol $1^{-1} / \mathrm{AgCl}$, buffer reference standard $\mathrm{pH} 4.0, \mathrm{pH} 7.2$, and $\mathrm{pH}$ 9.0, supplied by Crison.

\subsection{Apparatus}

Microwave Accelerated Reaction System 5 supplied by CEM Corporation, Matthews, (North Carolina, USA); electrode mod.4000-1 by Universal Sensor Inc. (New Orleans, LA, USA), coupled with an Amel potentiostat mod. 551 (Milan, Italy), connected to an Amel differential electrometer, mod. 631 and to an Amel analogical recorder, mod. 868; pHmeter CRISON GLP 22; Ultra-Turrax homogenizer mod. T8 by Ika 
Labortechnik (Germany); magnetic stirrer mod. F20ST by Falc Instrument (Bergamo, Italy); analytical balance mod. METTLER AE 420; technical balance mod. METTLER PM 460, CCD-Simultaneous ICP-OES, VISTA-MPX, Varian.

\subsection{Sample preparation}

Unio pictorum mancus: two aliquots to be analysed $(1 \mathrm{~g})$ were sampled from each mollusc: one was mineralized using a suitable solvent for analysis by plasma emission atomic spectroscopy; the other was treated in $6.0 \mathrm{ml}$ of phosphate buffer at $\mathrm{pH} 7.5$, by a homogenizer at $10000 \mathrm{rpm}$ for $5 \mathrm{~min}$, and analysed by (SOD) superoxide dismutase biosensor.

Viviparus ater: sample was homogenized in as small a volume as possible of phosphate buffer at $\mathrm{pH}$ 7.5. The solution was divided into two parts: the first was analysed by plasma emission atomic spectroscopy, the second by (SOD) biosensor.

\subsection{Plasma Emission Atomic Spectroscopy (ICP)}

The biosensoristic response has to be confirmed by the results of plasma emission atomic spectroscopy. This technique is highly reliable, reproducible and easy to use, with no chemical or spectral interference. Samples to be analyzed were carefully weighed when fresh, then placed in a teflon cylinder with $9.0 \mathrm{ml}$ of distilled water, $1.0 \mathrm{ml}$ of $\mathrm{HNO}_{3}(65 \%)$ and $1.0 \mathrm{ml}$ of $\mathrm{H}_{2} \mathrm{O}_{2}(40 \%$ $\mathrm{m} / \mathrm{v}$ ). Each sample was submitted to the following mineralization program: $5 \mathrm{~min}$ at $50 \%$ power; $3 \mathrm{~min}$ at $0 \%$ power (cooling); $5 \mathrm{~min}$ at $50 \%$ power $(100 \%$ power corresponds to $\left.300 \mathrm{~m}^{2} \mathrm{~kg} \mathrm{~s}^{-3}\right) ; 3 \mathrm{~min}$ at $0 \%$ power (cooling); $5 \mathrm{~min}$ at 50\% power; last cooling for $10 \mathrm{~min}$. All these solutions were filtered, diluted to $50 \mathrm{ml}$, and analyzed.

\subsection{Superoxide dismutase (SOD) biosensor}

The superoxide radical was determined by SOD biosensor obtained by coupling a transducer (amperometric Clark electrode for hydrogen peroxide) with superoxide dismutase enzyme immobilized in kappa-carrageenan gel. The gel containing the enzyme is sandwiched between a cellulose acetate membrane and a dialysis membrane (Campanella et al. 1999, 2000). Superoxide radicals were produced, in presence and in absence of the antioxidant, by reaction of oxidation of xanthine catalysed by xanthine oxidase, and the values of the recorded current were plotted versus xanthine concentration. The angular coefficients were calculated and the value of the anti-oxidant capacity was expressed by the following algorithm:

(RAC) "Relative Antioxidant Capacity" $=1-\left(\mathrm{m}_{\mathrm{c}} / \mathrm{m}_{\mathrm{x}}\right)$

$\mathrm{m}_{\mathrm{x}}=$ angular coefficient of the straight line obtained through successive additions of xanthine $(200 \mu l)$; $\mathrm{m}_{\mathrm{c}}=$ angular coefficient of the straight line obtained through successive additions of xanthine, but in the presence of the sample $(500 \mu \mathrm{l})$ possessing anti-oxidant properties.

\section{RESULTS}

Table 1 reports the manganese concentrations in 10 soft tissue samples analysed by plasma emission atomic spectroscopy. The wide variability of Mn-concentrations is mainly due to the different parts of the mussel body analysed. This shows how heterogeneous the distribution of manganese is in the mussel body. In fact, there are very different concentrations of manganese in the organs of the same species from the same lake (Ravera et al. 2003a). The samples with the highest $\left(\mathrm{N}^{\circ}\right.$ 2) and the lowest $\left(\mathrm{N}^{\circ}\right.$ 6) Mn concentration were homogenised and analysed by superoxide dismutase (SOD) biosensor. The results are reported in table 2 and schematized in figure 1.

Tab. 1. Manganese concentration in Unio pictorum mancus samples determined by plasma emission atomic spectroscopy.

\begin{tabular}{cc}
\hline Sample & $\mathrm{mg} \mathrm{kg}^{-1} \mathrm{ww}$ \\
\hline 1 & 307.48 \\
2 & 730.21 \\
3 & 244.26 \\
4 & 156.79 \\
5 & 330.00 \\
6 & 37.95 \\
7 & 228.71 \\
8 & 100.93 \\
9 & 94.07 \\
10 & 108.73 \\
\hline
\end{tabular}

Tab. 2. Values obtained by plasma emission atomic spectroscopy and by superoxide dismutase biosensor (RAC units) in Unio pictorum mancus.

\begin{tabular}{ccc}
\hline Sample & $\mathrm{mg} \mathrm{Mn} \cdot \mathrm{kg}^{-1} \mathrm{ww}$ & RAC units \\
\hline 2 & 104.23 & $0.600 \pm 0.007$ \\
6 & 176.61 & $0.696 \pm 0.010$ \\
\hline
\end{tabular}

The Mn concentration in Unio ranges from 100 $\mathrm{mg} \cdot \mathrm{kg}^{-1}$ (wet weight) to $200 \mathrm{mg} \cdot \mathrm{kg}^{-1}$, and appears to be correlated with the total antioxidant capacity according to the hypothesized central role and biological function of manganese against the radicals.

The relationship between total antioxidant capacity and $\mathrm{Mn}$ concentration was also evident in the soft tissues of Viviparus ater, although the Mn concentration in this mollusc ranged between $1.6 \mathrm{mg} \cdot \mathrm{kg}^{-1}$ (wet weight) and $7.2 \mathrm{mg}$ (Tab. 3, Fig. 2). The RAC until values of Viviparus, ranging from 0.53 to 0.86 (Tab. 3, Fig. 2), are of the same order of magnitude as those found for Unio $(0.60 \div 0.70)$. 


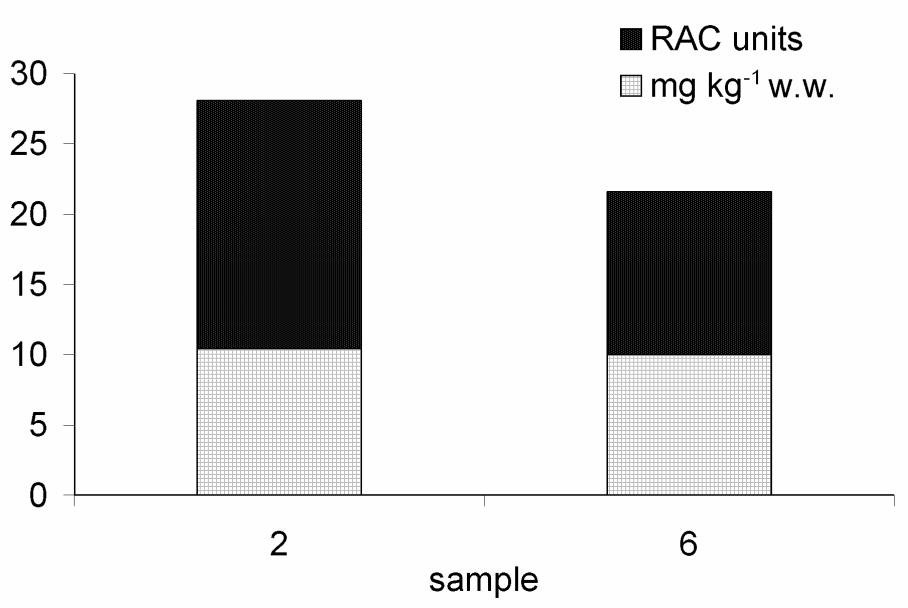

Fig. 1. Comparison between Mn concentration using plasma emission spectroscopy and total antioxidant capacity using SOD biosensor. To compare the experimental data graphically, the RAC units were multiplied by 100 and then divided by 6 , while Mn values were divided by 10 .

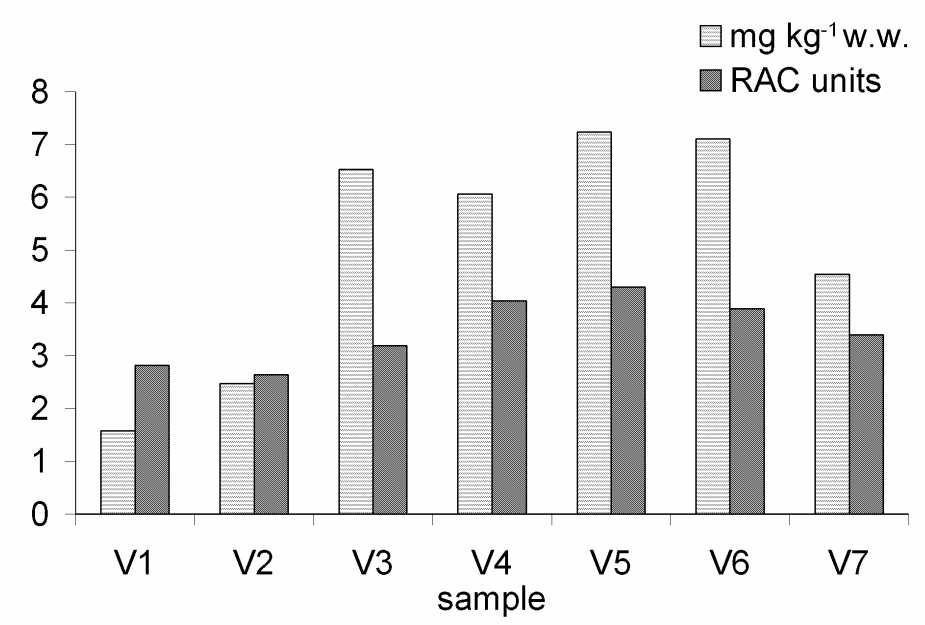

Fig. 2. Comparison between $\mathrm{Mn}$ concentration determined by plasma emission spectroscopy and total antioxidant capacity by SOD biosensor. To compare the experimental data graphically, the RAC units were multiplied by $5 . \mathrm{V} 1 \div \mathrm{V} 7=$ order number of 7 individuals.

Tab. 3. Values obtained by plasma emission spectroscopy and by superoxide dismutase biosensor (RAC units) in Viviparus ater.

\begin{tabular}{ccc}
\hline Sample & $\mathrm{mg} \mathrm{Mn} \cdot \mathrm{kg}^{-1} \mathrm{ww}$ & RAC units \\
\hline V1 & 1.57 & $0.563 \pm 0.010$ \\
V2 & 2.47 & $0.528 \pm 0.005$ \\
V3 & 6.53 & $0.637 \pm 0.005$ \\
V4 & 6.06 & $0.807 \pm 0.006$ \\
V5 & 7.23 & $0.859 \pm 0.004$ \\
V6 & 7.10 & $0.777 \pm 0.004$ \\
V7 & 4.54 & $0.679 \pm 0.006$ \\
\hline
\end{tabular}

\section{DISCUSSION}

Aquatic animals take up metals from both water and food. Differences in concentrations of the same metal in different species living in the same habitat are due to different types of food and/or different metabolic processes, such as excretion-rate and detoxification mechanisms.

Unio pictorum and Viviparus ater specimens used in our research were collected from the same habitat, in which they use similar organic particles as food; the former species accumulates a high concentration of manganese in its soft tissues, whereas the latter concentrates a very small amount of the same metal.

These characteristics make Unio pictorum and Viviparus ater useful species for testing the relationship between anti-oxidant capacity and manganese accumulation in molluscs.

Manganese concentration in individuals from the same population varies widely in Unio as well as in Viviparus, but Unio values are generally of two orders 
of magnitude higher than those found in Viviparus. Conversely, the order of magnitude of RAC (Relative Antioxidant Capacity) is the same for both molluscs; consequently, manganese efficiency as an antioxidant is much lower in Unio. Our initial question was answered by the interesting discovery that the antioxidant capacity in Unio and Viviparus increases with the increase of manganese concentration. The isoenzymes of the superoxide dismutase (SOD) catalyze the dismutation of the superoxide, assuming a central role in the organism's defence from the toxicity of oxygen by-products.

The prosthetic groups of these isoenzymes may be of different heavy metals, such as $\mathrm{Cu}, \mathrm{Zn}, \mathrm{Fe}$ and $\mathrm{Mn}$; manganese is a component of an anti-oxidant enzyme which protects the mussels from oxidative stress (Luo 2001). The results obtained clearly demonstrate the role played by manganese against free radicals and highlight the probable relationship between manganese concentration and its role in protecting the molluscs from oxidative stress.

\section{CONCLUSIONS}

In conclusion, the low concentration of manganese in Viviparus may be the result of the effective excretion of the metal, as was found for ruthenium (Ravera 1964).

Manganese accumulation in Unio tissues does not have any obvious effects, due to the detoxification processes by thioneins (High et al. 1997) and the transfer of manganese from the soft tissues to the organic matter of the shell (Nyström et al. 1996) and to calcium phosphate granules (Byrne 2000). In addition, the isoenzyme of the superoxide dismutase reduces the toxicity of the oxygen by-product.

It may be interesting for future research to test the combined effects of $\mathrm{Mn}$ and carotenoids on the antioxidant capacity in some species of freshwater and marine mussels. Such a project might start from the results obtained by Tewary et al. (2001) on a marine bivalve Perna perna. These authors observed a relationship between the resistance of bivalves to high concentrations of toxic metals and high concentration of carotenoids in the bivalve.

\section{ACKNOWLEDGEMENTS}

We are grateful to Mrs. Sandra Spence for the accurate English revision.

\section{REFERENCES}

Beone, G.M. \& O. Ravera. 2003. Vantaggi e limiti del monitoraggio ambientale mediante l'analisi chimica dei Lamellibranchi. Studi Trent. Sci. Nat. Acta Biol., 78: 79-84.

Bowen, V.T. 1950. Manganese metabolism of social Vespidae. J. Experim. Zool., 115: 175-203.

Bradley, H.C. 1907a. The occurrence of manganese in freshwater clams. Science, 25: 456.

Bradley, H.C. 1907b. Manganese. A normal element in the tissues of freshwater clams, Unio and Anodonta. J. Biol. Chem., 3: 151.
Byrne, M. 2000. Calcium concretions in the interstitial tissues of the Australian freshwater mussel Hyridella depressa (Hyriidae). In: E.M. Harper, J.D. Taylor \& J.A. Crame (Eds), The Evolutionary Biology of the Bivalvia. Geological Society, London, Special Publications, 177: 329-337.

Campanella, L., G. Favero \& M. Tomassetti. 1999. Superoxide dismutase biosensor for superoxide radical analysis Anal. Letters, 32(13): 2559-2581.

Campanella, L., G. Favero, L. Persi \& M. Tomassetti. 2000. New biosensor for superoxide radical to evidence molecules of biomedical and pharmaceutical preparations using a polymeric membrane ISE as detector. J. Pharm. Biomed. Anal., 23: 69-76.

Fukai, R. \& W.W. Meinke. 1959. Trace analysis of marine organisms: a comparison of activation analysis and conventional methods. Limnol. Oceanogr., 4: 398-408.

Gaglione, P. \& O. Ravera. 1964. Mn-54 concentration in fallout, water and Unio mussels of Lake Maggiore 19601963. Nature, 204: 1215-1216.

Grassé, G. 1960. Traité de Zoologie. V. Mollusques. Masson, Paris.

Gravato, C., Oliveira M. \& M.A. Santos. 2005. Oxidative stress and genotoxic responses to resin acids in Mediterranean mussels. Ecotox. and Environ. Safety, 61: 221-229.

High, K.A., V.J. Barthet, J.W. Laren \& J.S. Blais. 1997. Characterisation of metallothionein-like proteins from zebra mussel (Dreissena polymorpha). Environ. Toxicol. Chem., 16: 1111-1118.

Jorge, R.A.D.L.V.C. \& G.S. Moreira. 2005. Use of sodium dodecylsulphate and zinc sulphate as reference substances for toxicity tests with the mussel Perna perna (Linnaeus, 1758) (Mollusca: Bivalvia) Ecotox. and Environ. Safety, 61: 280-285.

Lowman, F.G. 1960. Marine biological investigations at the Eniwetok test site. In: Disposal of radioactive wastes. IAEA, Vienna, 2: 105-138.

Luo, J. 2001. Manganese Superoxide Dismutase. Medical Laboratories free radical and radiation biology program. University of Iowa, IA.

Malmstron, B.G. \& A. Rosenberg. 1959. Mechanism of metal ion activation of enzymes. Advances in Enzymology, 21: 131-167.

Markich, S.J. \& R.A. Jeffree. 1994. Absorption of divalent trace metals as analogues of calcium by Australian freshwater bivalves - an explanation of how water hardness reduces metal toxicity (review). Aquat. Toxicol., 29: 257-290.

Nyström, J., E. Dunca, H. Mutvei \& V. Lindh. 1996. Environmental history as reflected by freshwater pearl mussels in the River Vramsån, southern Sweden. Ambio, 15: 350-355.

O'Connor, T.P., A.Y. Cantillo \& G.G. Lauenstein. 1994. Monitoring of temporal trends in chemical contamination by NOAA National status and trends Mussel Watch Project. In: K.J.M. Kramer (Ed.), Biomonitoring of Coastal Waters and Estuaries. C.R.C. Press, Boca Raton (Florida).

Pelseneer, P. 1935. Essai d'ethologie zoologique d'après l'étude des mollusques. Acad. Roy. Belgique, Bruxelles.

Phillips, D.J.H. 1977. Effect of salinity on the net uptake of zinc by the commun mussel Mytilus edulis. Mar. Biol., 41: 79-88.

Ravera, O. 1964. The radioactivity of Viviparus ater, Crist. and Jan, freshwater mollusc, in relation to that of the sediment. Bull. FEPE, 10: 61-65.

Ravera, O. 2004. Importance and difficulties of research on the metal speciation in the aquatic ecosystem: an ecologist's viewpoint. Annali di Chim., 94: 495-504.

Ravera, O. \& L. Vido. 1961. Misura del Mn-54 in popolazioni di Unio pictorum, L. (Molluschi Lamellibranchi) del Lago Maggiore. Mem. Ist. ital. Idrobiol., 13: 75-84.

Ravera, O., R. Cenci, G.M. Beone, M. Dantas \& P. Lodigiani. 2003a. Trace element concentrations in freshwater 
mussels and macrophytes as related to those in their environment. J. Limnol., 62(1): 61-70.

Ravera, O., G.M. Beone, R. Cenci \& P. Lodigiani. 2003b. Metal concentrations in Unio pictorum mancus (Mollusca, Lamellibranchia) from of 12 Northern Italian lakes in relation to their trophic level. J. Limnol., 62(2): 121-138.

Tewari, A., H.V. Joshi, C. Raghunathan, V.G. Svravan Kumar \& Y. Khambhaty. 2001. Effect of heavy metal pollution

Received: July 2005

Accepted: October 2005 on growth, carotenoid content and bacterial flora in the gut of Perna viridis (L.) in in situ condition. Current Science, 81: 819-828.

Vinogradov, A.P. 1953. The elementary chemical composition of marine organisms. Memoirs Sears Foundation for Marine Research. New Haven, Connecticut. 